\title{
Analysis of SME Segment Lending Processes in Light of Credit Guarantees in the European Union*
}

\author{
Ádám Balog
}

Funding as a problem has ranked much lower on the list of SMEs' most daunting challenges since 2011, according to the ECB's SAFE survey. The accommodative monetary policy of the central banks in advanced markets coupled with the low interest rate environment has contributed to the fact that financing conditions have been considerably relaxed at global level since 2010. In the EU, 80-85 per cent of SME borrowing is realised through bank loans, thus entailing the risk that companies' access to finance may be constrained in conditions of financial turbulence, which threatens the development of productivity. Increasing the role of credit guarantees is an important tool in mitigating the impact of these trends, and it assists financial institutions in helping the SME sector with funds in a recession with greater certainty and lower risk.

Journal of Economic Literature (JEL) codes: E32, G15, G21, O16, O19

Keywords: credit guarantee, SME, banking system

\section{Situation of European SME sector and its access to finance}

According to the rules of the European Commission, small and medium-sized enterprises can be categorised as follows (Table 1): ${ }^{1}$

\section{Table 1}

EU definition of small and medium-sized enterprises

\begin{tabular}{c|c|c|c} 
Size & Staff headcount & Turnover & Balance sheet total \\
\hline Micro & $<10$ & $<€ 2$ million & $<€ 2$ million \\
\hline Small & $<50$ & $<€ 10$ million & $<€ 10$ million \\
\hline Medium & $<250$ & $<€ 50$ million & $<€ 43$ million \\
\hline
\end{tabular}

Source: European Commission

* The views expressed in this paper are those of the author(s) and do not necessarily reflect the offical view of the Magyar Nemzeti Bank.

Ádam Balog is the Chief Executive Officer of MKB Bank. E-mail: balog.adam@mkb.hu

The Hungarian manuscript was received on 22 September 2017.

DOI: http://doi.org/10.25201/FER.17.1.6282

${ }^{1}$ SME definition: http://ec.europa.eu/growth/smes/business-friendly-environment/sme-definition_en. Downloaded: 05 May 2017. 
All companies with a headcount below 250 employees and an annual turnover below EUR 50 million fall into the category of small and medium-sized enterprises (SMEs). In the European Union, these firms are dominant in the industry, construction and commerce segments, which are the most capital-intensive sectors. Thus maintaining funding to these businesses is a priority not only from the perspective of their own growth and operation, but also for the whole economy. Figure 1 shows that leverage is the highest in the above-mentioned sectors, therefore they are the most sensitive to changes in interest rates and fluctuations of the business cycle. Since SMEs account for a large proportion of companies with higher levels of leverage, and these sectors (e.g. construction) are strongly correlated with the shifts in GDP and are impacted heavily by the development of consumption (retail and wholesale trade), the way they access funds is key.

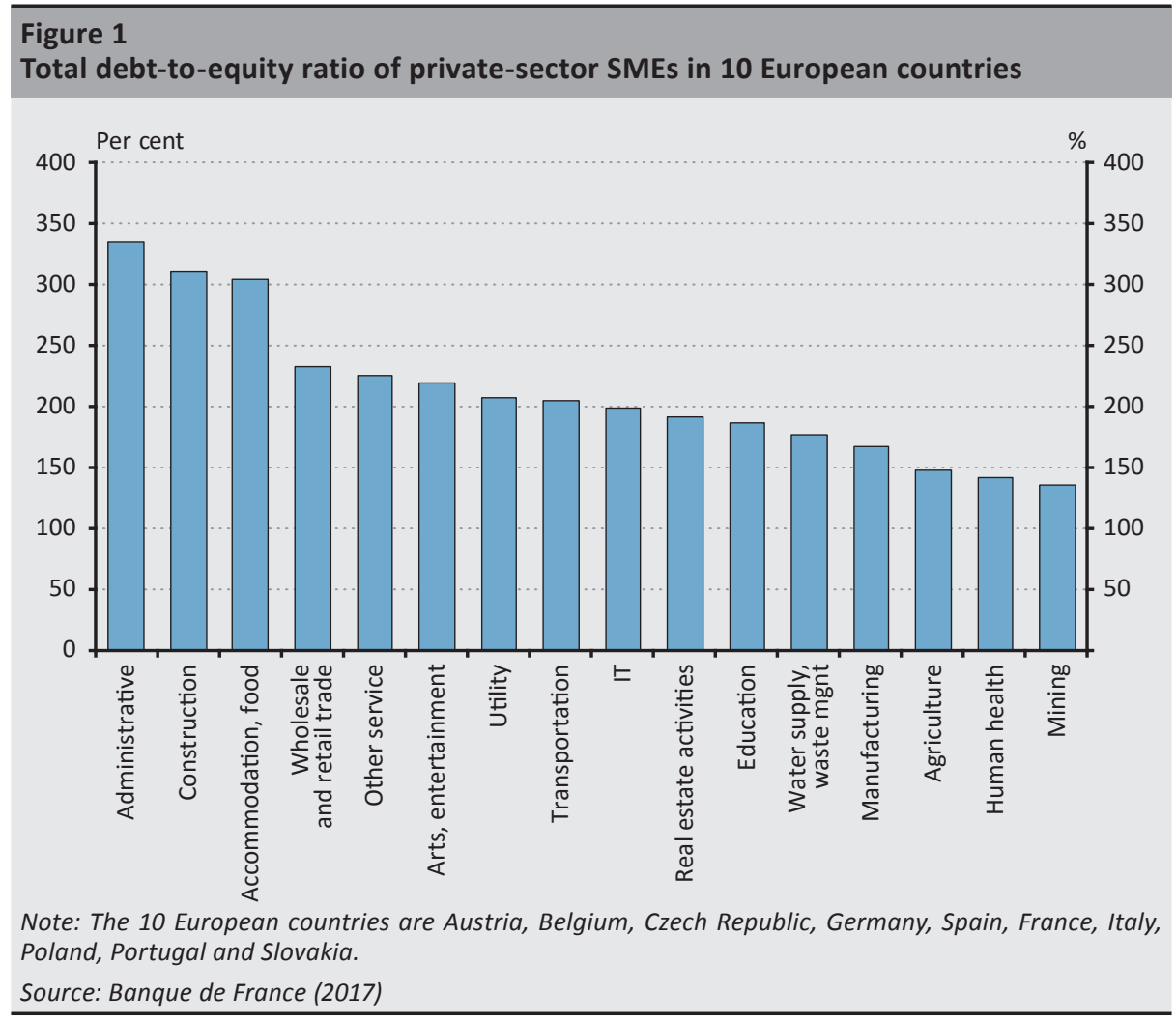

In the European Union, 80-85 per cent of SME borrowing is realised through bank loans. This is exactly the opposite to practice in the United States (US), where similar companies obtain 80-85 per cent of their funds from the capital markets (WSBI-ESBG 2015). The main forms of this include corporate bonds, private equity, venture capital, crowdfunding or hybrid solutions (Firoozmand et al. 2015). With 
respect to corporate bonds, issuances in both the EU and the US have declined considerably compared to the mid-2000s. According to European Central Bank data, non-financial institutions issued corporate bonds amounting to EUR 50 billion until September 2017 (see Figure 2). To put that into perspective, securities (corporate bonds) worth USD 1,100 billion were issued until September in the US.

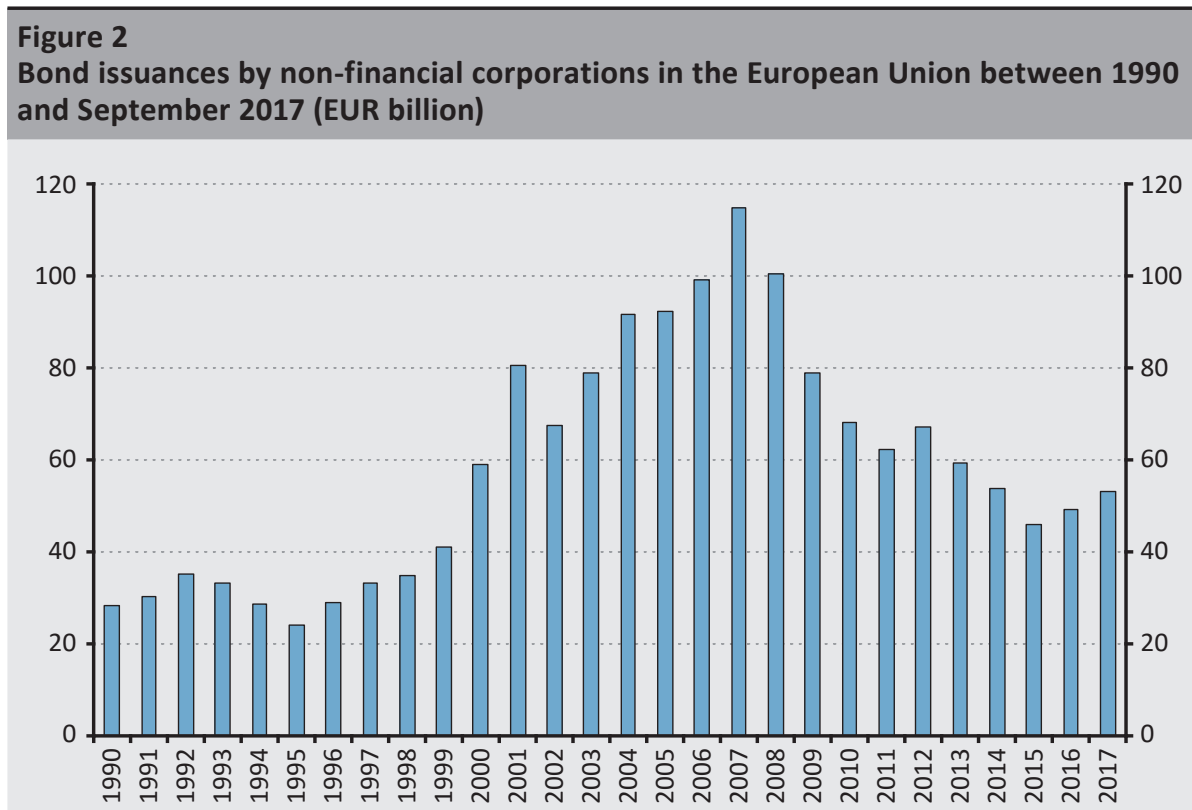

Source: European Central Bank (ECB 2017b)

From the perspective of economic development, SMEs play a central role in the EU as they account for 60 per cent of the continent's GDP, and employ around 90100 million people, approximately 70 per cent of the workforce. Currently, 22 million small and medium-sized enterprises operate in the EU. If these firms do not have appropriate access to the desired amount of funding in the appropriate structure, this may entail a drop in investments, postponed acquisitions and declining innovation. Lending activity contributes to economic growth through heightened investment activity. Appropriate external funding means entrepreneurship may be strengthened, new companies may be established, and businesses' economies of scale may also improve. In the rising phase of business cycles, risk is perceived to be lower by both borrowers and lenders driven by the improving labour market conditions and the greater propensity to consume. Companies can mitigate the short-term fluctuations in their profits through external funding, which may entail less variation in investments (Bodnár et al. 2014). 
In the latter case, it is important that market participants believe in the temporary nature of the downturn. If the business cycle loses steam, it may lead to a drop in business activity, lower profits and thus growing unemployment and declining consumption. These all increase risk and entail more subdued activity by the actors. Since this can turn into a spiral, the intervention - or more precisely the smoothing of volatility in the cycles - is crucial.

Since the 2008 crisis and thanks to central banks' near-zero interest rate policy and other measures, SME access to finance has been adequate (Figure 3), it is now not among the most pressing issues in the sector (ECB 2017a). This has not always been the case: in 2008 and 2011, financing issues proved to be the third (or, when disregarding the "Other" category, the second) gravest concern in the life of European SMEs, but since then it has been overtaken by the cost of labour, the lack of unskilled labour and the compliance with, and the complexity of, industry regulations.

\section{Figure 3}

Most typical problems of the SME sector between 2008 and 2016

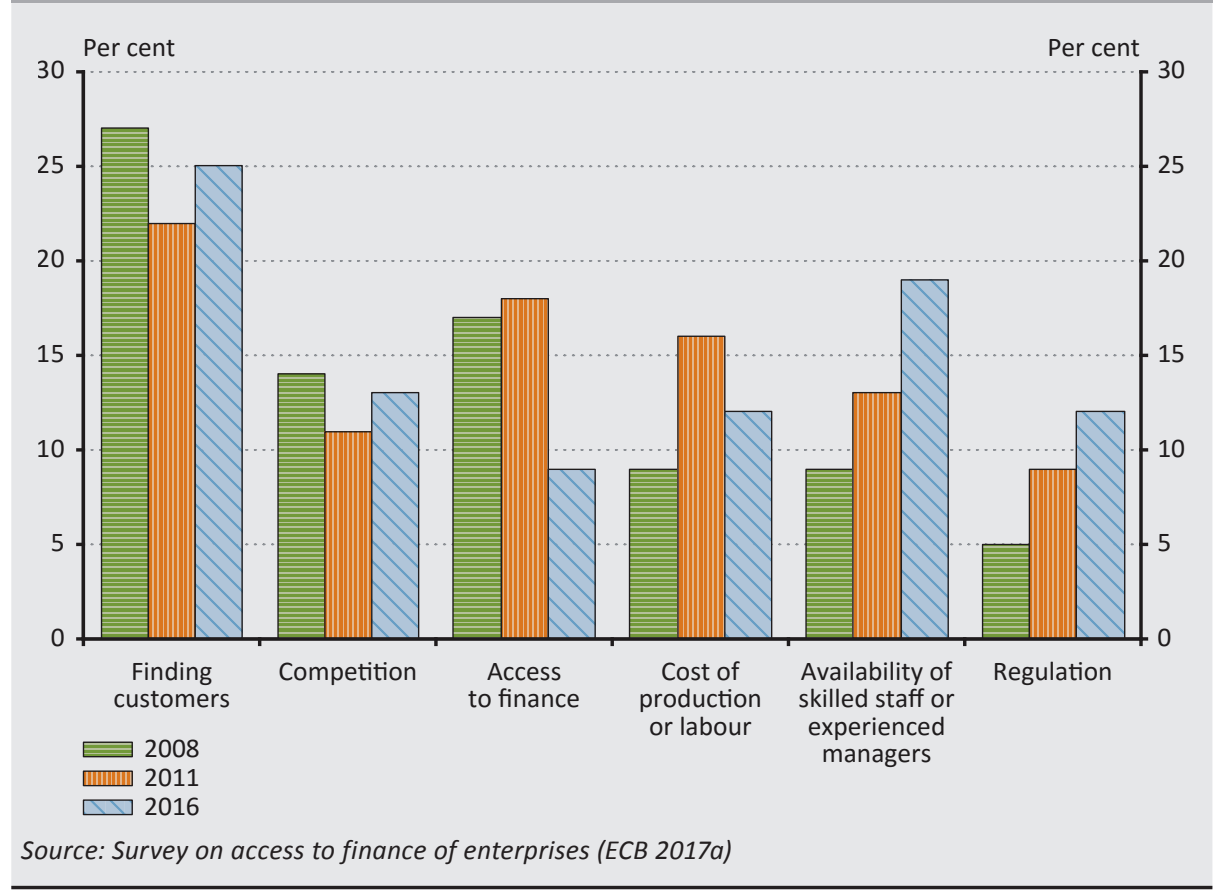


Economic recessions and the problem of access to credit or finance usually go hand in hand, in fact, they can even strengthen each other. However, in order to address the economic downturn as soon as possible, this is exactly the period when countercyclical measures - that can help mitigate the impact of the slump - should be implemented.

Monetary easing and the zero interest rate policy served exactly this purpose in the wake of the 2007-2008 crisis, albeit they achieved the desired effect in different ways across countries, depending on the maturity of the market. Since bank loans are much more dominant in the European Union, measures boosting lending in a recession may exert a positive impact over the economy of the whole continent.

The aim of the guarantee schemes related to SME borrowing is to provide access to credit even to firms that would otherwise be ineligible due to their past or inadequate collateral. In addition, guarantee schemes can provide SMEs access to credit even at the trough of the business cycle, thereby positively affecting GDP or mitigating the downturn. A recent survey covering guarantee institutions operating within national borders reveals that from the perspective of their own functioning, even these institutions themselves believe that the credit guarantees provided to the SME sector have the greatest potential, with 71 per cent of them responding along these lines (Chatzouz et al. 2017). Another important aspect may be that most entrepreneurs can provide less capital to their business than they would like (Evans-Jovanovic 1989).

The SAFE analysis by the European Central Bank (ECB 2017a) identifies eight factors that significantly influence credit supply and demand. All of these have improved in recent years, but according to the SMEs surveyed, the economic conditions and prospects only became favourable in the first half of 2017, and the availability of credit guarantees is still perceived negatively, which has not changed much since 2015. Substantial improvement can be seen in individual, firm-specific prospects, as well as in the willingness to lend on the part of banks, trading partners and external investors (see Figure 4). According to the SMEs surveyed, the conditions of credit guarantees have not improved recently, which suggests that companies would use this opportunity, but its availability or terms are not appropriate. 


\section{Figure 4 \\ Changes in factors affecting lending among European SMEs between 2013 and first half of 2017}

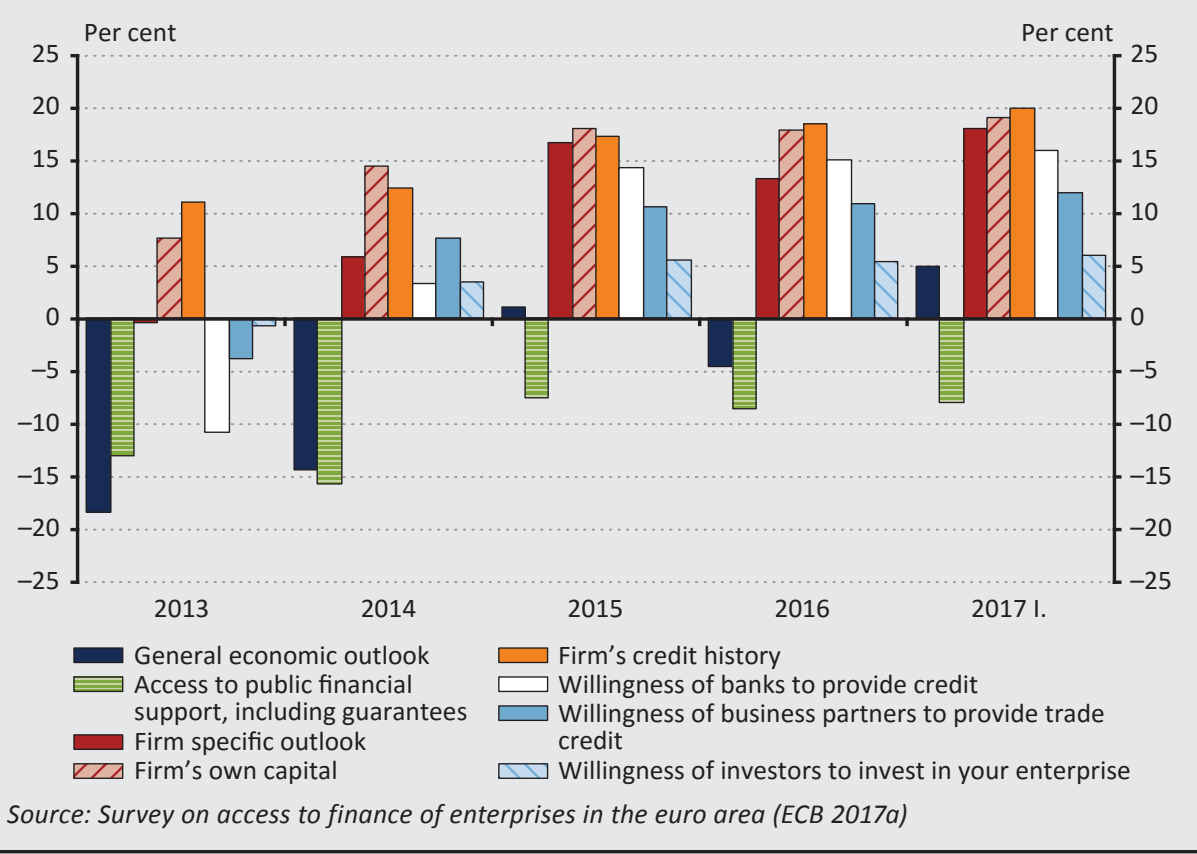

\section{Types of SMEs by regions}

The guarantee schemes in the different countries are important because even though there are efforts to manage the situation at EU level, different types of SMEs can be found in the various regions (Moritz et al. 2015). Six main groups can be differentiated (Table 2):

1. Mixed-financed companies, where SMEs use a wide range of financing; they comprise the second largest group (16.7 per cent of the total). They utilise loans from friends and family, retained earnings and external loans for financing. They can most typically be found in construction, and they innovate more than the average. Such firms can overwhelmingly be found in northern regions.

2. State-subsidised SMEs mainly have state-subsidised loans. Merely 7.2 per cent of all the SMEs belong here. They are small and medium-sized, usually family-owned firms that are widespread in the southern regions, and they dominate in industry.

3. Debt-financed SMEs rely almost exclusively on bank loans. This group is characterised by low growth and low innovation, and covers 16.1 per cent of 
the whole sector. Short-term loans and working capital loans are typical. They are also widespread in the southern region.

4. Flexibly financed SMEs make up 13.2 per cent of the sector, and they mostly obtain trade credit and bank overdrafts. They are usually microenterprises with a single owner, and they are typical in western regions. They exhibit average growth and usually low turnover.

5. Trade-financed SMEs cover 15.3 per cent of the sector. They are mostly familyowned small enterprises, characterised by low growth and an exposure to the commercial sector.

6. Internally financed SMEs, which are mainly typical in the eastern region and post-communist countries, usually solve their liquidity problems from internal sources of finance (e.g. retained earnings). At 31.4 per cent this is the largest group. It contains young, usually family-owned businesses mainly active in the services sector.

\section{Table 2}

Cluster analysis of European SMEs by financing

\begin{tabular}{|c|c|c|c|c|c|c|}
\hline Source of financing & $\begin{array}{l}\text { Mixed- } \\
\text { financed } \\
\text { SMEs }\end{array}$ & $\begin{array}{c}\text { State- } \\
\text { subsidised } \\
\text { SMEs }\end{array}$ & $\begin{array}{l}\text { Debt- } \\
\text { financed } \\
\text { SMEs }\end{array}$ & $\begin{array}{l}\text { Flexibly } \\
\text { financed } \\
\text { SMEs }\end{array}$ & $\begin{array}{l}\text { Trade- } \\
\text { financed } \\
\text { SMEs }\end{array}$ & $\begin{array}{l}\text { Internally- } \\
\text { financed } \\
\text { SMEs }\end{array}$ \\
\hline Retained earnings & $28 \%$ & $23 \%$ & $21 \%$ & $15 \%$ & $26 \%$ & $14 \%$ \\
\hline Subsidised loans & $15 \%$ & $100 \%$ & $2 \%$ & $0 \%$ & $2 \%$ & $0 \%$ \\
\hline Bank overdraft & $45 \%$ & $54 \%$ & $56 \%$ & $100 \%$ & $6 \%$ & $0 \%$ \\
\hline Bank loans & $36 \%$ & $55 \%$ & $95 \%$ & $0 \%$ & $0 \%$ & $0 \%$ \\
\hline Trade credit & $41 \%$ & $32 \%$ & $41 \%$ & $21 \%$ & $70 \%$ & $0 \%$ \\
\hline Other loans & $73 \%$ & $1 \%$ & $0 \%$ & $0 \%$ & $0 \%$ & $0 \%$ \\
\hline Leasing & $28 \%$ & $24 \%$ & $30 \%$ & $20 \%$ & $41 \%$ & $0 \%$ \\
\hline Capital & $24 \%$ & $4 \%$ & $0 \%$ & $0 \%$ & $0 \%$ & $0 \%$ \\
\hline Other (e.g. bonds) & $17 \%$ & $0 \%$ & $0 \%$ & $0 \%$ & $0 \%$ & $0 \%$ \\
\hline No external finance & $0 \%$ & $0 \%$ & $0 \%$ & $0 \%$ & $0 \%$ & $100 \%$ \\
\hline $\begin{array}{l}\text { Number of SMEs in the } \\
\text { group }\end{array}$ & 2,060 & 887 & 1,981 & 1,627 & 1,888 & 3,869 \\
\hline Share of group & $16.7 \%$ & $7.2 \%$ & $16.1 \%$ & $13.2 \%$ & $15.3 \%$ & $31.4 \%$ \\
\hline
\end{tabular}

As can be seen from Table 2, there are overlaps between the clusters, they are not entirely distinct categories. Most companies use at least four of the nine forms of financing outlined here (except for internally financed SMEs). 


\begin{tabular}{|c|c|c|c|c|c|c|}
\hline \multicolumn{7}{|c|}{$\begin{array}{l}\text { Table } 3 \\
\text { Geographical distribution of European SMEs by financing }\end{array}$} \\
\hline & $\begin{array}{l}\text { Mixed- } \\
\text { financed }\end{array}$ & $\begin{array}{c}\text { State- } \\
\text { subsidised }\end{array}$ & $\begin{array}{c}\text { Debt- } \\
\text { financed }\end{array}$ & $\begin{array}{c}\text { Flexibly } \\
\text { financed }\end{array}$ & $\begin{array}{l}\text { Trade } \\
\text { credit }\end{array}$ & $\begin{array}{r}\text { Internally } \\
\text { financed }\end{array}$ \\
\hline Eastern Europe & $14.4 \%$ & $6.3 \%$ & $11.4 \%$ & $9.8 \%$ & $12.3 \%$ & $45.8 \%$ \\
\hline Northern Europe & $23.7 \%$ & $3.5 \%$ & $11.2 \%$ & $11.6 \%$ & $22.6 \%$ & $27.4 \%$ \\
\hline Southern Europe & $16.1 \%$ & $9.8 \%$ & $17.3 \%$ & $12.4 \%$ & $17.5 \%$ & $26.8 \%$ \\
\hline Western Europe & $15.6 \%$ & $6.2 \%$ & $20.2 \%$ & $17.4 \%$ & $10.8 \%$ & $29.8 \%$ \\
\hline
\end{tabular}

With respect to geographical distribution (see Table 3), Eastern Europe is overwhelmingly dominated by internally financed SMEs (with 45.8 per cent of the total belonging to this group), while Northern Europe is more balanced because the latter has a share of 27.4 per cent. They are followed by mixed-financed companies (23.7 per cent), then trade credit-financed firms (22.6 per cent). The proportion of state-subsidised businesses is higher in southern parts of Europe than in the European Union as a whole. Western Europe is characterised by internally financed and debt-financed SMEs.

The distribution suggests several things: for example, the banking system is stronger and more mature in the west and the north, therefore these regions reflect a higher proportion of loan financing and lower state involvement. According to other analyses, in the regions where the banking system is more mature, companies are more likely to use trade credit. The high proportion of mixed-financed firms suggests that the capital market of the given region is mature; even though this is the case in the west (the capital market is more mature), the share of such businesses there does not differ markedly from the average (15.6 per cent compared to the 16.7 per cent average). In the case of mixed-financed firms, capital market financing can be observed, i.e. companies can also obtain funds in the form of shares and corporate bonds.

The higher-than-average state involvement in the southern countries points out another unique feature. In Italy, Spain, Greece and Portugal, not all non-performing loans have been resolved since the crisis, therefore the state's engagement is greater.

In Eastern Europe, the extreme share of internal financing is due to the fact that the banking sector and the capital markets of post-Soviet countries are less mature than in Western Europe. In such a situation, it is much harder to access external financing (bank loan, trade credit), thus most companies rely on friends and family and previously generated profits. It is important to note, however, that in the long run, improving financial development increases potential growth, but only to 
a certain extent. An excessively large financial system does not have a positive impact (Cecchetti - Kharroubi 2012; Arcand et al. 2012).

The countries damaged more severely by the crisis are also different. There has been a significant downturn in southern countries since 2008 , so banks there shed their risky assets, firms' access to credit deteriorated considerably, while operating costs soared. As a result, businesses in these regions relied on trade credit and state-subsidised loans instead. Analyses show that state involvement has a positive effect on companies' access to credit. In the UK, SMEs that were unable to access state funds also had a more difficult time obtaining external financing on the market (Murray - Lott 1993). The same holds true for the SME sector in the US (Mina et al. 2005; 2013). State-subsidised firms receive funds from credit institutions more easily, even if the overall financial conditions are not optimal. It also has to be noted that if lending activity contracts, firms increasingly turn towards other forms of financing, such as factoring or leasing (Moritz et al. 2015) to offset the declining credit supply. This may be facilitated by credit guarantees.

\section{Anomalies affecting external financing}

Economic turbulence aside, many banks are not eager to extend loans to certain SMEs, even if the economy is prospering. This is because acquiring information on the creditworthiness of mostly young companies is expensive or almost impossible due to the lack of relevant data. In this case, regional banks may provide a solution to some extent (Lang et al. 2016), as such institutions are more familiar with the regional companies. Another disadvantage is that these firms have no assets that could serve as collateral for loans. So many SMEs that otherwise have appropriate and viable projects or developments cannot realise them due to a lack of funds.

The latter is usually referred to as the SMEs' financing gap, and it is claimed that the inefficient lack of external financing is caused by the information asymmetry (Chatzouz et al. 2017). This asymmetry can lead to inappropriate borrowers being picked by banks when they cannot differentiate between good and bad projects, or to banks setting higher lending rates as they do not have sufficient high-quality information about the given SME (Pozzolo 2004). According to the analysis by Stiglitz et al. (1981) the low transparency and inadequate collateral of SMEs increased the information asymmetry and the risks arising from that (moral hazard). In some countries, this was the incentive behind the creation of credit guarantees. Moral issues also emerge, since the limited liability in the case of a bankruptcy may encourage borrowers to engage in excessive risk-taking (Farhi - Tirole 2011; Holmstrom - Tirole 1997; Kuniyoshi - Tsuruta 2014).

The collateral used for securing the loan is not always adequate during borrowing. On the one hand, smaller firms cannot always provide adequate collateral, and 
on the other hand, the collateral is usually worth more to the company than the bank, which is also a real problem. According to a survey by the European Central Bank and the European Commission (second half of 2016), the lack of adequate collateral is one reason why SMEs do not have access to an appropriate amount of external financing. While for large enterprises, inadequate collateral was cited as a reason in merely 0.5 per cent of the cases, the same figure was 5 per cent for SMEs. The collateral for the loan may reduce the bank's risk arising from the information asymmetry. However, providing collateral also increases the cost of the loan, as it entails additional legal and administrative expenses. According to a study by Chen (2006), one major source of collateral is real estate owned by SME owners. During a recession, property prices tend to fall, so borrowers are less likely to obtain new collateral, which may lead to the liquidation of the collateral. The procyclicality of property prices and the inefficient liquidation process may further deepen the recession. The time it takes to sell the collateral and the collateral's value are important because the established value (e.g. determined by a valuer) does not necessarily coincide with the fair market value.

Inadequate credit supply may also be due to the fact that monitoring smaller firms and obtaining appropriate information about them is more difficult. While a publicly traded company's every move is accurately documented and is accessible by investors, this is much more difficult in the case of SMEs. Data are available on SMEs as well of course, but their quality may be questionable due to inappropriate accounting and record-keeping systems. Another issue is economies of scale, since it is by no means negligible whether a bank invests energy in the loan application process of a small company or the financing of a large enterprise, i.e. unit costs are crucial. Another issue in connection with SMEs is that many of them are young businesses without a history that can be used by the lender to draw appropriate conclusions regarding the future.

Although financing issues have become marginal in the life of SMEs in recent years, two factors have emerged that may impede companies' access to credit. The high concentration of the banking sector, i.e. when a large portion of the market is controlled by only a few banks, leads to SMEs being crowded out from lending. In light of the European banking consolidation in recent years, this may be a real problem in the life of smaller companies. The other factor is the potential fall in property prices, which may set SME financing back as many firms offer real estate as collateral in exchange for the loan (Chen 2006; Ryan 2014).

One aspect of the above-mentioned problems, i.e. the information asymmetry, can partly be resolved by regional banks. Local banks have stronger ties to local SMEs, therefore the necessary information can be obtained more swiftly and cheaply. According to an EIB finding based on an Italian example, local banks know the given 
region better, and the link between the bank and the borrower is also stronger (Lang et al. 2016).

\section{Credit guarantee}

Within the framework of a credit guarantee agreement, the guarantor institution offers a demand guarantee to the financial institution with respect to the loan granted to the given company. In such a scenario the bank runs a lower risk, since in the event of a default by the client the guarantor institution honours a predetermined portion of the outstanding amount towards the bank.

The credit guarantee fund is an independent third party between the bank and the borrower when the latter does not meet all the conditions that are necessary for the bank. Thus the guarantee fund provides some sort of security to the bank, and indirectly enables the firm to obtain a loan. Guarantee institutions are usually established with state involvement, both in developed and developing markets. They are usually non-profit institutions, but they have some obligation to be selfsufficient.

Guarantee institutions can provide guarantees against their capital for an amount exceeding it several times, so their leverage can be as high as 20-25 (Davies 2007; Levitsky 1997). The amount of the guarantee is usually around 30-80 per cent of the loan. After 5 years of operation, an appropriately functioning guarantee fund can reach leverage levels equivalent to 5 times its capital, then after 7-10 years this figure can be as high as 10 . If counter-guarantees are permitted as well (like in Japan or Germany for example), leverage can be over 20 (O'Bryan 2010). The credit guarantee scheme can be extended to most loans, which can affect the establishment of new firms, the acquisition of new machinery and equipment or the supplementation of working capital, however, there may be differences in this respect between individual countries and guarantee institutions.

The guarantee can be provided in several ways: in a retail (individual), portfolio or wholesale system. In the retail (individual) system, the individual firms, their credit applications and projects are assessed on a case-by-case basis, then the decision on providing the guarantee is taken. This procedure generates huge costs and takes many working hours. For a portfolio-level guarantee, similar loans are pooled when the decision on providing the guarantee is made, i.e. bank administration is not burdened by individual assessments and the approval process. Based on the framework determined in advance with the guarantee institution, the bank alone decides on what to put in the portfolio. In the wholesale system, there is no direct relationship between the credit guarantee institution and the lender/borrower. The credit guarantor's task is to provide a guarantee to non-bank intermediaries; one typical example of this is the Central Guarantee Fund in Italy. 
Normally the lender is responsible for the debtor's credit appraisal, and the same applies for a credit guarantee, too, although this task can be performed by the guarantor and the lender as well. Usually the lender has the appropriate infrastructure for coordinating the process. Nevertheless, the principal/agent problem may arise between the credit guarantor and the credit institution, which may imply excessive risk-taking and underinvestment in the credit appraisal process (Chatzouz et al. 2017).

In certain cases, banks can use credit guarantees to mitigate their RWA exposure. Within the framework of Basel III and the CRR/CRD regulation, banks can reduce the capital requirement on loans secured by a credit guarantee. This is determined by the CRR/CRD or by EBA standards. All this became truly interesting for banks after the crisis, since financial institutions faced considerable capital write-offs, and in the past 10 years, both the regulation and capital requirements have become more stringent, thus the operation of banks has become more secure, but also more complicated and costly.

The establishment of Western European credit guarantee institutions began in the mid-1990s, they are partly state-owned, non-profit companies but they have an obligation to be self-sufficient (wholly private guarantee institutions can be found only in France and Italy), there is no restriction on their leverage and they enjoy tax holidays. They mostly target SMEs in order to increase lending activity in that segment. They offer guarantees to banks, leasing companies and other financial institutions, mostly in the case of working capital loans, investments and trade credit. The fees related to the guarantee are paid by the borrower, and they depend on the amount of loan. Coverage ranges from 34 to 81 per cent and is for 10-15 years. The distribution of losses is usually pari passu (Chatzouz et al. 2017).

Of course, credit guarantees also entail costs, typically consisting of an annual fee and an upfront fee, which reflects the riskiness of the projects. The guarantor may also charge an administrative fee, and determine whether the fees should be borne by the lender or the borrower. However, it has to be noted in this context that riskbased pricing is not always used; it is not typical in Hungary for example.

Guarantee schemes can be examined from the perspective of specific countries or the EU. In the latter case, the COSME, the SME Initiative and the InnovFin programmes are designed to foster SME financing. The same holds true, to a smaller extent, for the Cultural and Creative Sector Guarantee Facility, which provides opportunities to SMEs that are engaged in the cultural and creative sectors, or the EaSI - Employment \& Social Entrepreneurship, which seeks to bolster the labour market and facilitate mobility within Europe with its guarantee scheme. 
The COSME runs with a total budget of EUR 2.3 billion until 2020. Its aim is to help SMEs access funds more easily, promote entrepreneurship, and provide an environment conducive to launching new companies and to growth. Within the scheme, the guarantee may be up to 50 per cent of the principal, and it can be used by companies employing up to 249 people, i.e. micro, small and medium-sized enterprises can all participate in it. One major advantage of the scheme is that it is free, and that it reduces banks' RWA exposure if the guarantee is not conditional. The latter is important because thanks to the guarantees, one financial institution can finance more companies than if it did not avail of this opportunity.

The goal of InnovFin is to help innovative SMEs access appropriate funding. The scheme can be used in the case of loans between EUR 25,000 and EUR 7.5 million (with maturities between 1 and 10 years), and by firms with up to 499 employees. It provides credit guarantees to SMEs that develop some innovative product or grow rapidly (where the headcount or revenues have grown by 20 per cent annually in the past 3 years). The scheme's cost is an annual $0.5-0.8$ per cent, it covers up to 50 per cent of the extended loan in the case of losses, and it also reduces banks' RWA exposure. For start-ups, a credit guarantee is important because access to credit is also hindered if the company has no "track record".

The above-mentioned guarantee institutions operate at international level, in contrast to the guarantee institutions in individual countries that mainly perform activities within the borders of the given country. The most important actor in international credit guarantee services is the EIF, which is part of the EIB Group. It includes the SME Initiative, InnovFin as well as COSME. The EIF offers guarantees for SME loans and leases, and may also offer counter-guarantees for portfolios of local credit guarantee institutions.

\section{Credit guarantee and European practice}

Credit guarantees do not completely eliminate the anomalies of external financing, and therefore cannot address the root cause of the problem either; but they can contribute to the smoother functioning of the credit market. In addition to state involvement, the credit guarantee is the tool that can give companies an opportunity to access appropriate funding even in an unfavourable economic climate. Ultimately, this could also mitigate the extent of the economic downturn. The only question is whether the credit guarantee truly helps mitigate a downturn.

Underlining the importance of guarantee funds as frequently heard among SMEs, an examination of 50,000 corporate loans in Italy showed that banks demand relatively more collateral from SMEs than when lending to large enterprises (Pozzolo 2004). Bigger companies also access external funds much more easily, therefore the SME sector may be at a disadvantage due to its size (and thus also due to 
its riskiness) (Beck et al. 2005). Economies of scale are important here as well, since it is important to a bank whether it finances the project of a small firm or a multinational corporation.

The EIB analysis notes that the guarantee scheme can only be beneficial to the economy if it is implemented carefully (Kraemer et al. 2017). Since the state is among the owners in most cases, the fallout from any default is ultimately borne, to some extent, by the taxpayer. And this has been an extremely sensitive issue since the 2008 crisis, in fact, the EU prohibits "bailouts", i.e. when a financial institution in, or on the verge of, bankruptcy is rescued by the state. Between 2008 and 2012, the EU spent EUR 568 billion on saving banks close to bankruptcy, and the bill was footed by taxpayers. Instead, the so-called "bail-in" should be used, under which the financial institution is recapitalised by shareholders, bondholders and ultimately even the largest depositors. This was first employed in practice with the crisis management in Cyprus in 2012-2013.

The administrative burden associated with guarantee schemes has diminished considerably in recent years, and the process has been expedited in several places, therefore these schemes can still be considered the primary tools in the hands of the state for facilitating access to credit for SMEs. This is the case even though the spectre of moral hazard is still present. However, it can be avoided or mitigated through the exact definition of loss sharing and the coverage ratio. Loss sharing can be pari passu, where losses are fixed irrespective of the amount. The collected debt is allocated based on the predetermined distribution between the lender and the guarantor. In the case of subordinated debt, the lender's claim is satisfied first, before the guarantor. At the portfolio level, under a "first-loss" scheme, the full burden of the default is borne up to the predetermined amount of the loss, while under a "second-loss" guarantee, the guarantor only covers the second part of the loss. Moreover, if the coverage ratio is high, the lender may feel encouraged to neglect the debtor's monitoring and the assessment of its risks.

The OECD has found that the overwhelming majority of guarantee schemes target young and innovative firms to reduce unemployment and increase productivity (Kraemer et al. 2015; Kraemer et al. 2017). The advantage of guarantee institutions is that they are present in the lending process as a third party, thus the disbursement of the funds is ultimately assessed by a market-based institution, i.e. the bank. Credit guarantee institutions mostly operate within national borders, which makes the geographical distribution appropriate and enables regional banks to serve the needs of the companies operating in the given area much more efficiently.

It is clear that credit guarantees can help transfer the default risk (so it is similar to derivative and futures products, which have also been developed for the appropriate management of risks), but it can also realise industry or geographical diversification. 
Risk analysis may also be strengthened, since the credit guarantor takes part in the process too, and regulatory arbitrage can also emerge as the credit guarantee may help enable the lender to meet the regulatory requirements.

The operation of, and data on, guarantee institutions in the EU and neighbouring countries are summarised by the AECM (European Association of Guarantee Institutions). According to the latest data, in the EU the value of the guarantees offered relative to GDP is the highest in Italy, Portugal and Hungary. While in most EU countries the guarantees offered amount to $0.2-0.5$ per cent of GDP, the ratio is approximately 1.7-2 per cent in the first three countries (Figure 5).

\section{Figure 5 \\ Credit guarantees issued in countries as a percentage of GDP between 2015 and 2016}

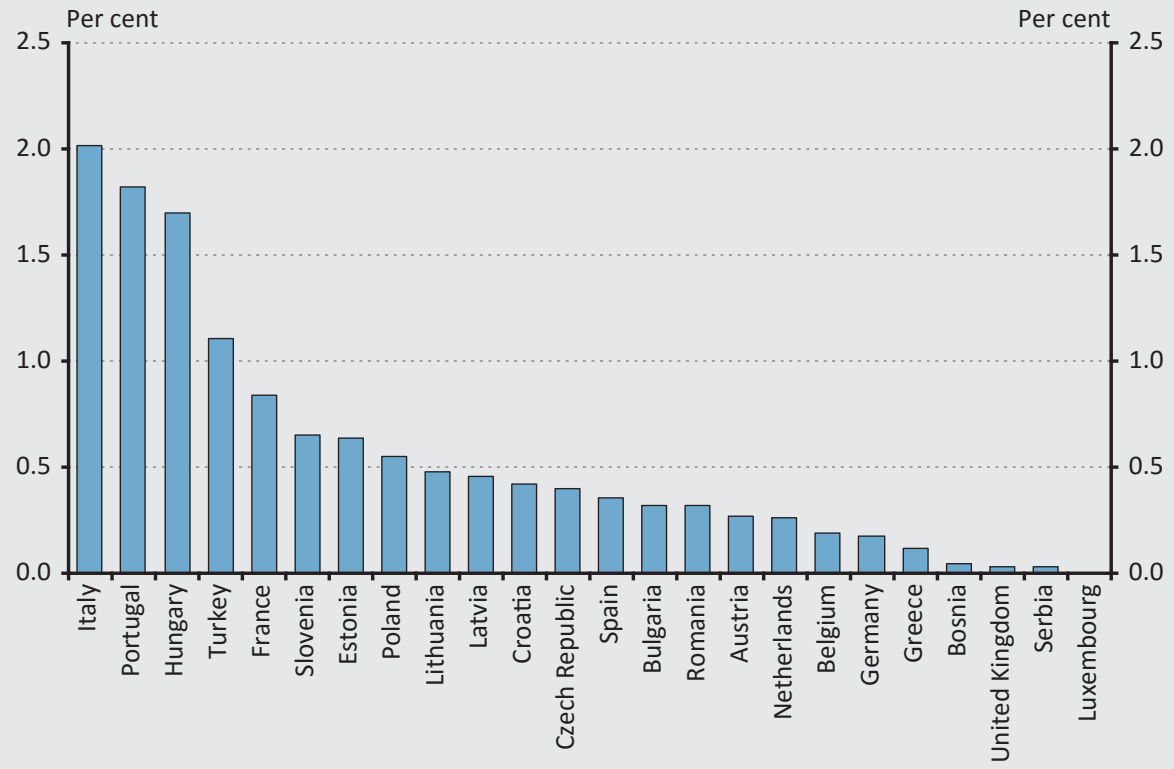

Source: AECM (Kraemer et al. 2015 and Kraemer et al. 2016)

- According to 2016 data from the AECM, in that year the 42 members provided guarantees amounting to approximately EUR 30 billion in 26 European countries to 2.8 million SMEs, helping create 400,000 new firms. On average, banks ran 30 per cent of the risk, while the rest was covered by credit guarantee institutions (Kraemer et al. 2017).

Credit guarantee schemes have been expanded considerably in recent years, especially as a result of the response to the crisis. The guarantee institutions 
operating within national borders stepped up their activities during the crisis, but there was extremely sluggish demand for loans by SMEs, therefore these schemes were unable to mitigate the impact of the recession. Institutions mostly bolstered working capital loans, since companies needed most help here on account of the crisis. Yet the increased activity in providing credit guarantees also posed a challenge to institutions, as this required more capital. Historical data show that 22 per cent of guarantee institutions received the necessary capital, while 50 per cent could only access it temporarily (Chatzouz et al. 2017).

According to the most recent EIB survey (Chatzouz et al. 2017), 91 per cent of the surveyed banks in the EU use credit guarantees, however, their share is insignificant compared to banks' total SME loans: merely 20 per cent of the banks reported that at least 10 per cent of their total SME loans are linked to a credit guarantee. Banks mostly use credit guarantees because SMEs' collateral is inadequate and riskier than the average, but another important factor is that risky assets can be reduced in this manner, which puts financial institutions in a favourable position under the stricter regulations implemented after the crisis.

According to the survey, banks are also convinced that the advertisements of guarantee institutions do not target the SME sector, therefore potential borrowers do not even know what opportunities are open to them if they do not have adequate collateral or their project is risky.

60 per cent of banks believe that credit guarantees have no impact on whether a particular loan becomes non-performing or not, while 35 per cent believe that the guarantee increases the likelihood of default. Cowan et al. (2015) argue that the chance of the loans of companies participating in a guarantee scheme becoming non-performing in the first 24 months is 1.67 per cent higher than that of those who do not have a guarantee, although the authors admit that credit guarantees do facilitate SME financing.

Few studies are available in the EU about the impact exerted by credit guarantees on the economy and SME lending. The reason behind this is that reliable and available data are scarce. The 2015 study by the European Commission and the EIF examined, using the "difference in difference" method, the various economic effects of a multi-year programme for companies, in particular small and medium-sized enterprises (SMEs), exerted on the participants in the programme and the control group between 2005 and 2012 (Asdrubali - Signore 2015). The analysis covered 10 countries from Central and Eastern Europe, and 0-10-year-old companies with 1-250 employees. According to the findings, the SMEs that participated in the programme increased their headcount by 17.3 per cent in the first five years, and their revenue grew by 19.6 per cent as compared to the control group. The boost in employment was the most significant in Romania and the Czech Republic. The 
analysis also shows that micro and young companies enjoyed the greatest advantage in the programme: while the smallest firms managed to raise their headcount by 18 per cent and their turnover by 25 per cent, the corresponding figures for the young companies, i.e. less than 5 years old, were 34 per cent and 27 per cent.

Nonetheless, in the short run (0-3 years), the productivity of the businesses in the programme dropped (by 9-11 per cent), and this difference disappeared only over the medium term. The authors claim that this was because of the potential misallocation of the capital and funds received after the guarantee. Moreover, as most such companies did not have loans in the two years prior to the guarantee, the disadvantage may also have been caused by adjusting to the new situation, for example the management of the newly emerging leverage.

However, the operation and perception of credit guarantees may depend largely upon the economy's overall performance. The Polish LDF guarantee fund provided several well-performing guarantees in the rapid growth phase of the business cycle (1998-2000). In the recession after the 2000s, as non-performance ratios increased, it refused to accept offers, therefore it had no reason to be interested in mitigating the economic downturn (Bennett et al. 2005).

The amount of credit guarantees relative to GDP is the highest in Italy, and most SMEs that obtained credit guarantees also operate here. In fact, according to the AECM database, there were over 1.3 million such firms in 2016 (Kraemer et al. 2017). The examination of the Italian SME sector showed that depending on the type of collateral provided by the borrower, i.e. physical or personal collateral, such as a credit guarantee where a third party intervenes in the case of a bankruptcy/ default, the borrower's probability of default with physical collateral was no different from zero (Pozzolo 2004). Therefore the claim that banks require more collateral to reduce moral hazard is false (Boot et al. 1991 and 1994). By contrast, the probability of default is positive and significant in the case of credit guarantees, i.e. banks use credit guarantees as an incentive in the case of moral hazard. With physical collateral, there is a positive correlation regarding the relationship between the bank and the borrower and its duration, while the correlation is negative in the case of a credit guarantee. The borrowers that have been in contact with the given financial institution for over 20 years are much more likely to provide physical collateral, simply because in such a case it is more likely that the bank will "lend a helping hand" in financial difficulties.

The analysis also found that banks demand more collateral from small firms than from large companies. The physical collateral offered by the smallest 20 per cent of businesses was over three times as high as that of the largest corporations. The gap was not that wide with credit guarantees, since in that case the collateral for the loans of the smallest firms was 1.2 times that of the largest businesses. 


\section{Conclusion}

The role of credit guarantee institutions in the financing of SMEs in the EU became increasingly important in the mid-1990s when the first such entities appeared. Their role is crucial because, in contrast to the US, the SME sector obtains 80-85 per cent of its external funds from banks and bank products (loans, factoring, trade credit, etc.). In an economic downturn, the dynamics of bank lending decline, and both borrowers and lenders become risk-averse. Thus SMEs do not obtain adequate funding, which can further deepen the recession, as investments fall, companies' profits nosedive, unemployment rises and the propensity to consume decreases. The question is to what extent can credit guarantees (whether international or domestic) reduce this slump, or smooth the fluctuations that interrupt the rising business cycles. The international studies and analyses show a mixed picture, and the latter are also incomplete, since accurate and available data sources are rare.

The overview demonstrates that although there are international solutions in the EU for credit guarantees, the differences between the regions call for local, domestic funds. The cluster analysis of the companies in the individual regions illustrates that different conditions should be expected depending on, for example, the source of finance used or the financial system's level of development.

The banking system has been subject to strict regulation since the 2008 crisis, and is now more costly to operate. Credit guarantees can thus not only facilitate the SME sector's access to funds, but may also be an appropriate tool for reducing banks' risky assets, in compliance with regulatory requirements. Yet the overall economic situation affects guarantee funds too, since when there are lots of non-performing loans, the funds may back out instead of improving the economic situation through their activities.

Bolstering the SME sector would have several effects. Since these businesses employ around 70 per cent of the economically active population in the EU and generate around 60 per cent of the continent's GDP, strengthening them would greatly improve Europe's economic situation and prospects. The increased activity of credit guarantee institutions in a recession could reduce volatility in the SME sector's profits and operations, thereby making the labour market situation, and thus also consumption indirectly, which is a cornerstone of economic growth, more stable. In addition, investments would become more balanced and predictable, which is also a decisive factor in GDP growth. 


\section{References}

AECM (2017): Representative of guarantee institutions in Europe -fostering SMEs' growth. www.aecm.eu. Downloaded: 13 September 2017.

Arcand, J-L. - Berkes, E. - Panizza, U. (2012): Too Much Finance? IMF Working Paper, WP/12/161, June.

Asdrubali, P. - Signore S. (2015): The economic impact of EU guarantees on credit to SMEs. Discussion Paper 002. https://ec.europa.eu/info/sites/info/files/economy-finance/dp002 en.pdf. Downloaded: 13 September 2017.

Banque de France (2017): Database. www.bach.banque-france.fr/?lang=en. Downloaded: 13 September 2017.

Beck, T. - Demirgüç-Kunt, A. - Maksimovic, V. (2005): Financial and legal constraints to growth: Does firm size matter? The Journal of Finance, 60(1): 137-177. https://doi.org/10.1111/j.1540-6261.2005.00727.x

Bennett, F. - Alan, D. - Harriet, B. (2005): Do credit guarantees lead to improved access to financial services? Recent evidence from Chile, Egypt, India and Poland. Financial Sector Team, Policy Division Working Paper, Department for International Development, London.

Bodnár, K. - Kovalszky, Zs. - Kreiszné Hudák, E. (2014): Recovery from crises and lending. Financial and Economic Review, 13(4): 57-85. http://english.hitelintezetiszemle.hu/ letoltes/3-bodnar-en.pdf

Boot, A. W. A. - Thakor, A. V. (1994): Moral Hazard and Secured Lending in an Infinitely Repeated Credit Game. International Economic Review, 35: 899-920. https://doi.org/10.2307/2527003

Boot, A. W. A. - Thakor, A. V. - Udell, G. F. (1991): Secured lending and default risk: Equilibrium analysis, policy implications and empirical results. Economic Journal, 101: 458-472. https://doi.org/10.2307/2233552

Cecchetti, S. G. - Kharroubi, E. (2012): Reassessing the impact of finance on growth. BIS Working Papers No. 381.

Chatzouz, M. - Gereben, Á. - Lang, F. - Torfs, W. (2017): Credit guarantee schemes for SME lending in Western Europe. EIB Working Paper (2017/02).

Chen Y. (2006): Collateral, loan guarantees, and the lenders' incentives to resolve financial distress. Quarterly Review of Economics and Finance, 46: 1-15. https://doi.org/10.1016/ j.qref.2004.10.001 
Cowan, K. - Drexler, A. - Yańez, A. (2015): The effect of credit guarantees on credit availability and delinquency rates. Journal of Banking and Finance, 59, 98-110.

https://doi.org/10.1016/j.jbankfin.2015.04.024

Davies, I. (2007): People's Republic of China: Development of small and medium-sized enterprise credit guarantee companies. Asian Development Bank.

ECB (2017a): European Central Bank: Survey on the access to finance of enterprises in the euro area (2009-2017). https://www.ecb.europa.eu/stats/ecb_surveys/safe/html/ index.en.html. Downloaded: 17 November 2017.

ECB (2017b): European Central Bank: Bond issue database. https://www.ecb.europa.eu/ stats/financial_markets_and_interest_rates/securities_issues/html/index.en.html. Downloaded: 15 November 2017.

Evans, D.S. - Jovanovic, B. (1989): An estimated model of entrepreneurial choice under liquidity constraints. The Journal of Political Economy, 97(4): 808-827. https://doi.org/10.1086/261629

Farhi E. - Tirole J. (2011): Collective moral hazard, maturity mismatch and systemic bailouts. American Economic Review 102(1): 60-93. https://doi.org/10.1257/aer.102.1.60

Firoozmand, S. - Haxel, P. - Jung, E. - Suominen, K. (2015): State of SME finance in the United States in 2015. TradeUp Capital Fund and Nextrade Group, LLC, March.

Holmstrom, B - Tirole, J. (1997): Financial Intermediation, Loanable Funds and The Real Sector. The Quarterly Journal of Economics, 112(3): 663-691.

https://doi.org/10.1162/003355397555316

Khwaja, A.I. - Mina, A. (2005): Do lenders favor politically connected firms? Rent provision in an emerging financial market. The Quarterly Journal of Economics, 120(4): 1371-1411. https://doi.org/10.1162/003355305775097524

Kraemer-Eis, H. - Lang, F. - Torfs, W. - Gvetadze S. (2015): European Small Business Finance outlook. EIF Research and Market Analysis, Working Paper 2015/32.

Kraemer-Eis, H. - Lang, F. - Torfs, W. - Gvetadze, S. (2016): European Small Business Finance outlook. EIF Research and Market Analysis, Working Paper 2016/35.

Kraemer-Eis, H. - Lang, F. - Torfs, W. - Gvetadze S. (2017): European Small Business Finance outlook. EIF Research and Market Analysis, Working Paper 2017/43.

Kuniyoshi, S. - Tsuruta, D. (2014): Adverse selection and moral hazard in the Japanese public credit guarantee schemes for SMEs. CEPR's Policy Portal. 
Lang, F. - Signore, S. - Gvetadze S. (2016): The role of cooperative banks and smaller institutions for the financing SMEs and small midcaps in Europe. EIF Research and Market Analysis, Working Paper 2016/36.

Levitsky, J. (1997): Credit guarantee schemes for SMEs: An international review. Small Enterprise Development, 8(2): 4-17. https://doi.org/10.3362/0957-1329.1997.013

Mina, A. - Lahr, H. - Hughes, A. (2013): The demand and supply of external finance for innovative firms. Industrial and Corporate Change, 22(4): 869-901. https://doi.org/10.1093/icc/dtt020

Moritz A. - Block H. J. - Heinz A. (2015): Financing patterns of European SMEs: An empirical taxonomy. EIF Research \& Market Analysis, Working Paper Nr. 30.

Murray, G. C. - Lott, J. (1993): Have UK venture capitalists a bias against investment in new technology-based firms? Research Policy, 24(2): 283-299. https://doi.org/10.1016/00487333(93)00767-N

O’Bryan W. E. (2010): An analysis of small business loan guarantee funds. Thesis. Retrieved from: https://digitalcommons.unl.edu/cgi/viewcontent.cgi?article=1003\&context=arch_ crp_theses. Downloaded: 13 September 2017.

Pozzolo, A. F. (2004): The role of guarantees in bank lending. EFMA 2004 Basel Meeting Papers. Paper available at https://doi.org/10.2139/ssrn.498982

Ryan, R. M. - O'Toole, C. M. - McCann, F. (2014): Does bank market power affect SME financing constraints? Journal of Banking \& Finance, 49 (December): 495-505. https://doi.org/10.1016/j.jbankfin.2013.12.024

Stiglitz, J.E. - Weiss, A. (1981): Credit rationing in markets with incomplete information. The American Economic Review, 71(3): 393-410.

WSBI-ESBG (2017): Financial systems in Europe and in the US: Structural Differences where banks remain the main source of finance for companies. Research Paper, www.wsbi-esbg.org. Downloaded: 03 May 2017. 